\title{
術後痕痕声帯に対する音声改善手術の経験
}

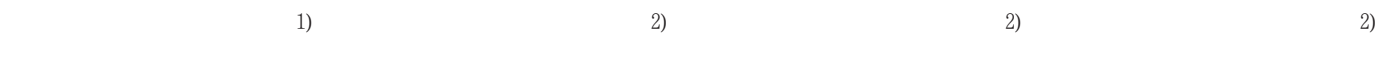 岡田 信 也 ${ }^{3)} \cdot$ 渋 谷 正 (1) $^{11}$ 飯 田 政 弘 ${ }^{4)}$}

\section{An Experience of Surgical Treatment for Vocal Fold Scarring}

\author{
Etsuyo Tamura'1), Hiroyuki Fukuda', Yuko Mori' ${ }^{2)}$ \\ Makoto Miyamoto2), Shinya Okada ${ }^{3)}$, Masato Shibuya ${ }^{1)}$ \\ and Masahiro Iida ${ }^{4)}$
}

\begin{abstract}
[Introduction] It has been reported that satisfactory surgical treatment is difficult to accomplish on cases with post-operative vocal fold scarring where flexibility has decreased. In the present study, the primary goal was to attain voice improvement for a professional singer, who had undergone laryngeal micro-surgery repeatedly. We removed scar tissue and performed autologous fat augmentation thereby successfully improving the wave motion of mucosa during phonation.

The result of our study on the changes of acoustical analyses are reported.

[The Case and the Course] The patient was a 60-year-old female folk singer. She had a history of smoking and had undergone laryngeal micro-surgery for polypoid degeneration of the vocal folds several times in the past. Mucosal depression was noted on left vocal fold. Using a stroboscope, mucosal wave motion was determined to be partially lacking on the left, and a deficiency of glottal closure was seen. In order to repair the vocal fold defect, autologous fat augmentation was performed. After the operation, her daily conversation voice had improved; however, no improvement of her singing voice was noted and mucosal defect remained. The patient was a professional singer and had a strong desire for her voice to be improved further. Subsequently, using laryngeal microscope, we tried to remove the intra-mucosal scar tissue and to inject fat tissue. Post-operatively, mucosal defect had diminished almost completely and wave motion during phonation had improved.

[Summary] The results of the study suggest that the removal of scar tissue and fat augmentation seem to be effective surgical treatments for vocal fold scarring.
\end{abstract}

Key words : scar tissue, wave motion, autologous fat augmentation

\section{I.は じめに}

一般に，いわゆる声門閉鎖不全疾患のなかで, 術後痏痕 など, 声帯の可撓性が低下した例に対する音声改善手術は, 困難であるといわれている.

今回われわれは, 複数回, 喉頭微細手術をうけた職業歌 手症例に対して, 音声の改善を目的として, 粘膜内の痏痕 組織を除去した後に, 自家脂肪注入術を施行し良好な結果 がえられたので報告する.

\section{II. 症}

例

1) 東海大学医学部付属八王子病院耳鼻咽喉科

2 ) 国際医療福祉大学東京ボイスセンター

3 ) 東海大学医学部付属大磯病院耳鼻咽喉科

4 ) 東海大学医学部専門診療学系耳鼻咽喉科

1) Department of Otorhinolaryngology, Tokai University School of Medicine, Tokai University Hachioji Hospital

2 ) Tokyo Voice Center, International University of Health and Welfare

3 ) Department of Otorhinolaryngology, Tokai University School of Medicine, Tokai University Oiso Hospital

4 ) Department of Otorhinolaryngology, Tokai University School of Medicine 
められた.

\section{治療経過：}

(1)声帯内自家脂肪注入術：2006年 2 月27日, 東海大学医 学部付属東京病院にて, 全身麻酔下に, 声帯遊離縁部の形 成を目的として, 㚘頁部脂肪組織を用いて, 声帯内自家脂肪 注入術を行なった. 筋層の浅い部分から粘膜固有層浅層に かけて, $1 \mathrm{cc}$ 注入した.

痒痕部に，十分な脂肪の注入は困難だったが，下唇を中 心として声帯の全体的な増量は可能だった.

術後 8 ヶ月目の発声時喉頭ストロボスコープ所見では, 瘕痕部の粘膜波動はやや改善されていたが, 粘膜陥凹部が 残存しており，歌唱時の音声改善には至らなかった.

患者は職業歌手で, 音声の更なる改善の希望か漒かった ため, 全身麻酔下に喉頭の顕微鏡下精査を予定した.

(2)痏痕組織除去および注入術：2006年11月20日, 粘膜波 動の認められなかった部分は, 鉗子で触れてみると硬く, 瘏痕組織の存在が推定された。 乥こで, 声帯上面の粘膜を 切開して, 粘膜固有層浅層の㾗痕組織を除去したのちに, 粘膜固有層のやや深層に自家脂肪を $0.5 \mathrm{cc}$ 注入した.

術後, 2 ヶ月目の喉頭ストロボ所見では, 粘膜陥凹部は ほぼ消失し, 粘膜波動に改善がみられた.

(3)音響分析 : 術前および術後に録画されたストロボスコ ピー検査時のデジタルビデオ画像と共に録音された音声の

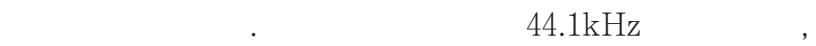
波形整合法により基本周期系列と最大振幅系列を求めた. また, 基本周期のゆらぎとして $\mathrm{PPQ}$ と JP, 振幅のゆら ぎとして $\mathrm{APQ}$ と $\mathrm{SP}$, 喉頭雑音として $\mathrm{NNEa} と \mathrm{NNEb}$ をロ声の検査法第 2 版口に記載されている式に従って計算 した ${ }^{11}$.

图 1 ・2 は, 術前, 脂肪注入術後, 㓔痕組織除去および 脂肪注入術後の $\mathrm{PPQ}$ 等の音響パラメータを, 経時的にプ ロットしたものである.

平均基本周波数の $200 \mathrm{~Hz}$ 付近の楽な発声時では, 初回 の脂肪注入術後, 杂隹音成分は増加した. しかし, 㾉痕組織 除去後に脂肪注入術を施行した後は, すべてのパラメータ

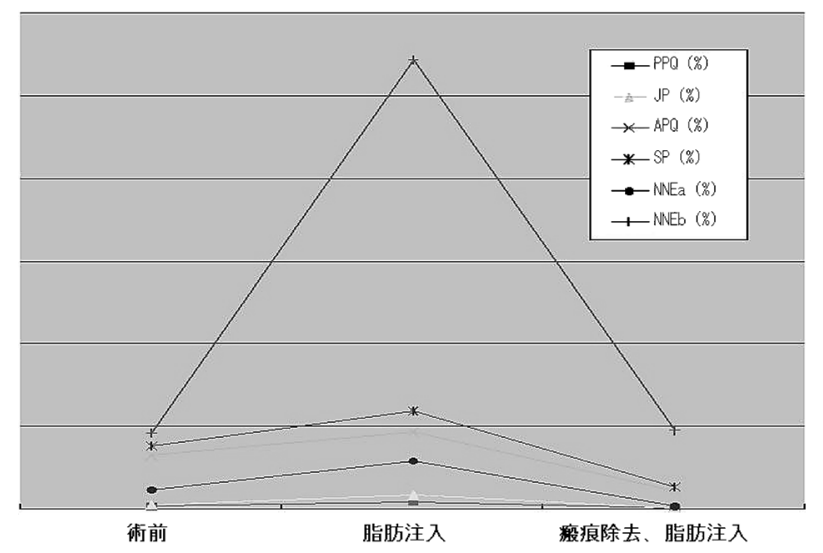

図 1 音響学的パラメータの変化: 平均基本周波数の $200 \mathrm{~Hz}$ 付近での楽な発声時
で改善傾向か認められた (図 1 ).

また, 図 2 の $400 \mathrm{~Hz}$ 付近の発声時では, 脂肪注入術の みでもすべてのパラメータに改善傾向が認められ, 废痕除 去後はさらに兴の傾向が高くなった.

$$
\text { III. 考察 }
$$

喉頭微細手術でとり扱われる主な疾患は, 声帯ポリープ, 声帯結節, ポリープ樣声帯などである. これらに対する手 術操作は, メスや鉗子による切除術であり，一般には縫合 を行わないため, 弚の治癒過程は, 二次治癒であり, 上皮 化は欠損部に応じて数日から数週間のうちに完成する. 治 癒過程には, 炎症期, 肉芽形成期, 細胞外基質形成期およ び再構築期があり, 弚れ光れの時期は互いに重なりあって

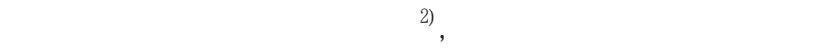
用する細胞成長因子があるといわれている. 特に, 細胞外 基質形成期には，TGF- $\beta$ が作用しコラーゲンの合成が促 進するといわれている.

いっぽう, 声帯に加わる外科的侵襲の治癒過程が, 術後 音声に大きく影響するために喉頭微細手術が, 音声外科手 術といわれるにもかかわらず, 声帯の創傷治癒に言及した 報告は少なく ${ }^{3,4)}$, 最近になって, 声帯粘膜の創傷治癒に おける細胞成長因子，特に，TGF- $\beta$ について検討がされ るようになってきた ${ }^{5 \sim 7)}$.

Tranilast の肥厚性痏痕に対する効果は肥満細胞からの ケミカルメディエータの遊離抑制や単球やマクロファージ からのサイトカインの遊離抑制により, 線維芽細胞の増殖 抑制, 線維芽細胞からのコラーゲンの合成抑制が起こるこ とによるといわれ，皮膚科，形成外科領域での有効性が報 告されている ${ }^{8,9)}$ ．筆者らは, イ又声帯の創傷モデルにお いて, Tranilast を局所投与し, 術後の肉芽形成について 検討した結果, Tranilast 非投与側に比較して，投与側声 帯において, 術後の膠原線維の増生が抑制されていたこと を報告した ${ }^{10)}$. したがって， Tranilastの投与により，音 声外科手術後における肉芽組織の増生か軽減できる可能性 が推察された.

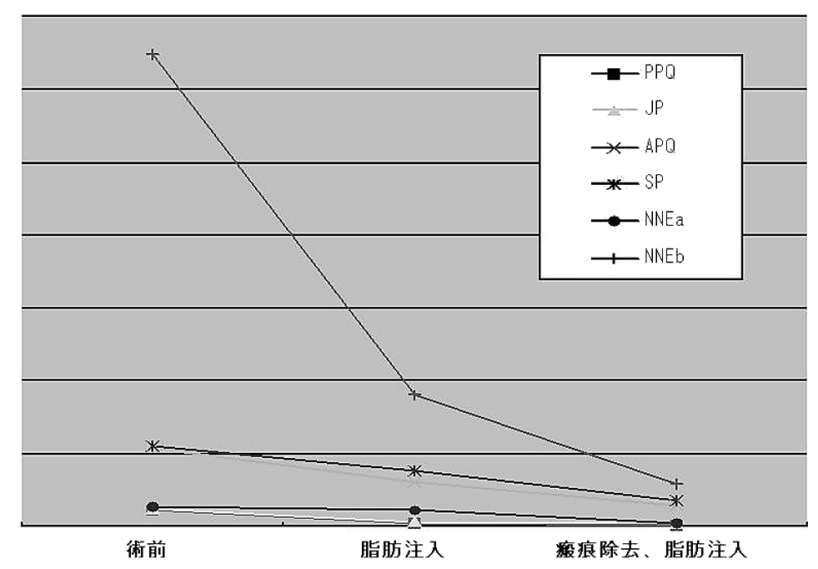

図 2 音響学的パラメータの変化: 平均基本周波数の $400 \mathrm{~Hz}$ 付近での発声時 
しかし，不幸にして，術後に起こった㓔痕声帯に対する 音声改善手術は困難であるといわれている. 弚の理由は, 㿍痕声帯には, 二つの問題点があるからである. すなわち, 第一に, 声帯粘膜の一部欠損という容量の低下, 第二に, 粘膜波動の欠如という粘膜の可撓性の低下という 2 点であ る. 今回, これらを解決する目的で, 喉頭顕微鏡下での音 声改善手術を行い良好な結果を得ることができた。

声帯内注入術は, 手技が比較的簡単であり, 粘膜に創面 を形成しないので, 術後に期待する程の効果が得られなかっ たとしても, 音声が悪化する危険が少ないという理由から, 声帯溝症などの声門閉鎖不全疾患に対する治療の一つとし て行われてきた，弚の効果としては，i) 声門閉鎖不全の 改善によって, 発声持続時間が延長する, ii ) 新たな声帯 遊離縁部の形成によって, 声帯振動が改善する, などが考 えられる. 注入物質としては, シリコン ${ }^{11)}$, コラーゲン ${ }^{12)}$ などが報告されてきたが, 脂肪組織は他の注入材料とは異 なり, 粘性が粘膜固有層と近似していると報告され ${ }^{13)}$, 粘 膜内に注入しても粘膜波動を障害しないと考えられる. 声 帯術後痏痕に対する脂肪による増量療法は, 粘膜切開後に 脂肪組織を移植する方法 ${ }^{14 \sim 16)}$ や切開後注入する方法 ${ }^{17,}{ }^{18)}$, 注入のみ ${ }^{19)}$ などが, 報告されている. しかし, 皮下に脂 肪組織を移植する動物実験では, 1 〜 $3 \mathrm{~mm}$ の長さのブ ロックでも移植後に血流障害による変性がおこりやすいと

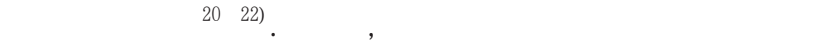
では, 吸引脂肪より, 明視下に摘出し細切した脂肪を注入 した方が, 壤死が少ないといわれている ${ }^{23,24)}$. したがっ て, 術創の管理の簡便さに加えて, 注入脂肪の生着という 観点からも, 明視下で脂肪を採取し, 細切して注入する方 法がもっとも適切であると考えられ，筆者は頬部脂肪体を 採取して使用している25).

既成の音声外科手術とは異なり，疲痕を除去するという 新しい概念の手術なので, 術後の音声の改善を $100 \%$ 保証 できるものではない. したがって，術前より悪化すること はなくても, 術後に音声がどの程度改善するかについては 不明な部分があることを十分に説明し, 同意を得る必要が ある。

また, 術後, 再疲痕化の傾向がないかどうか, 注意深く 経過を観察する必要はある. しかし, 他に臨床応用が可能 な治療法がない現状では, 本方法は有用な方法であると考 えられた。

IV. 結 論

粘膜内の痏痕組織を除去し, 兴のやや深層に脂肪組織を 注入する方法は, 発声時の粘膜波動のみならず, 音響学的 な検討でも改善か認められ, 術後瘕痕症例に対する音声改 善手術として有効な方法であると考えられた.

最後に, 音響分析につき, 直接御指導賜りました東京大 学医学部耳鼻咽喉科今川博先生に深謝いたします.

なお, 本論文の一部は第20回日本喉頭科学会総会・学術
講演会 (2008年 3 月, 佐賀市) にて口演した.<smiles>[Y]</smiles>

1) 粕谷英樹 : 声の音響分析. 声の検査法 (第 2 版 基礎 編), ( 日本音声言語医学会編) 117 150, 医歯薬出 版, 東京, 2002.

2) Clark RAF : Cutaneous tissue repair, Basic biologic consideration. I. J Am Acad Dermatol 13 : 701〜 725, 1985.

3) 北原哲, 福田宏之, 鈴木安恒ほか：Laryngomicrosurgery の基礎的研究. 日気食会報 $22: 11 \sim$ 14, 1977.

4）大築淳一：声帯創傷治癒に関する基礎的研究. 耳鼻 $28:$ 53〜65, 1982.

5) 田村悦代, 北原 哲, 中之坊学ほか：声帯内注入材 料に関する基礎的研究. 喉頭 $6: 122$ 129，1994.

6) Broadley C, Gonzalez DA, Nair R, Koriwchak MJ, Ossof RH, Davidson JM : A tissue-culture model for the study of canine vocalfold fibroblasts. Laryngoscope 105 : 23 27, 1995.

7) Walner DL, Cotton RL, Williging JP, Bove KE, Toriumi DM : Model for evaluating the effect of growth factors on the larynx. Otolaryngol Head Neck Surg 120 : 78 83, 1999.

8）須貝東夫, 菊池伸次, 市川 潔: アレルギー疾患治 療薬 Tranilast の Cytokine 産生・遊離に対する抑 制効果. 応用薬理 43: 409 414, 1992.

9) 郡司裕則, 舘下 亨, 小野一郎ほか：トラニラスト の瘕痕形成抑制作用に関する実験的研究. 日形会誌 $15:$ 721 779, 1995.

10)田村悦代, 北原 哲, 小倉雅實ほか：音声外科手術 後の肉芽増殖に対するトラニラストの効果に関する 検討. 日気食会報 $52: 10 \sim 16,2001$.

11) 福田宏之：注入用 Silicone による vocal rehabilitation. 日耳鼻 $73: 106 〜 156,1970$.

12) 高山悦代, 福田宏之, 川井田政弘ほか：Vocal Rehabilitation としての声帯内アテロコラーゲン注入術. 日気食会報 $41:$ 196〜201，1990。

13) Chan WD, Titze IR : Viscosities of injectable biomaterials in vocal fold augmentation surgery. Laryngoscope 108 : 725 731, 1998.

14) Woo P, Rahbar R, Wang Z : Fat implantation into Reinke's space: a histologic and stroboscopic study in canine. Ann Otol Rhinol Laryngol $108:$ 738 744, 1999.

15) 西山浩一郎, 廣瀬 肇, 井口芳明ほか : 声帯溝症に 対する声帯内自家脂肪. 筋膜移植術 104 : 1151 1155, 2001.

16) Hsiung MW, Kang BH, Pai L et al : Combination of fascia transplantation and fat injection into 
the vocal fold for sulcus vocalis: long term results. Ann Otol Rhinol Laryngol 113 : 359 366, 2004.

17) Sataloff RT, Spiegel JR, Hawkshaw M et al : Autologous fat implantation for vocal fold scar: a preliminary report. J Voice 11:238 246, 1997.

18) Neuenschwander MC, Sataloff RT, Abaza MM et al : Management of vocal fold scar with autologous fat implantation: Perceptual results. J Voice 15 : 295 304, 2001.

19) Hsiung MW, Woo P, Minasian A et al : Fat augmentation for glottic insufficiency. Laryngoscope $110:$ 1026 1033, 2000.

20) Smahel J : Experimental implantation of adipose tissue fragments. Br J Plast Surg 42 : 207 211, 1989.

21) Niechajev I, Sevcuk O : Long-term results of fat transplantation: clinical and histologic studies.
Ann Plast Reconstr Surg 94 : 496 506, 1994.

22) Carpaneda CA, Ribeiro MT : Study of the histologic alterations and vibility of the adipose graft in humans. Aesthetic Plast Surg 17 : 43 47, 1993.

23) Hill DP, Meyers AD, Harris $J$ : Autologous fat injection for vocal cord medialization in the canine larynx. Laryngoscope 101 : 344 348, 1991.

24) Zaretsky LS, Shindo ML, deTar M et al: Autologous fat injection for vocal fold paralysis: long-term histologic evaluation. Ann Otol Rhinol Laryngol $104:$ 1 4, 1995.

25）田村悦代, 福田宏之, 飯田政弘 : 㚘頁部脂肪体を用い た声帯内脂肪注入術. 日耳鼻 $111:$ 91〜 95， 2008.

別刷請求先 干 192-0032 東京都八王子石川町1838 東海大学医学部付属八王子病院耳鼻咽喉科

田村悦代 